\title{
Effect of GA3 on Biochemical Attributes and Yield of Summer Tomato
}

\author{
M. S. Rahman ${ }^{*}$, M. A. Haque and M. G. Mostofa \\ Crop Physiology Division, Bangladesh Institute of Nuclear Agriculture, Mymensingh, \\ Bangladesh
}

Corresponding author : :siddiq_bina17@yahoo.com

\begin{abstract}
An experiment was carried out in pots at Bangladesh Institute of Nuclear Agriculture, Bangladesh to evaluate influence of different concentrations of GA3 on biochemical parameters at different growth stages in order to maximize yield of summer tomato var. Binatomato-2. The concentrations of GA3 were 0, 25, 50, 75 and $100 \mathrm{ppm}$. They were applied at three stages, namely root soaking of seedlings before transplanting, vegetative and flowering stages. The experiment was laid out in a randomized complete block design with four replications. Results indicated that the highest chlorophyll and soluble protein contents were recorded when GA3 was applied through root soaking followed by vegetative stage and the lowest was found at the flowering stage. In contrast, the highest nitrate reductase activity was observed when GA3 was applied at the vegetative stage and the lowest activity was recorded at the flowering stage. The applications of 50-75 ppm GA3 had significantly encouraged the bio-chemical parameters studied at 50 DAT. The amount of GA3 applied at different stages had significant influence on the yield and yield attributes of summer tomato. The highest plant height was recorded when 50 ppm of GA3 was applied at the vegetative stage. While, the longest time to first fruit setting was required when the roots of the seedlings were soaked in 100 ppm GA3 solution. The application of 50 ppm GA3 by root soaking had significantly increased the number of flowers, fruits and fruit yield per plant but similar results were achieved when only 25 ppm GA3 was applied at the flowering stage. The fruit yield of tomato per plant increased linearly with the increased number of flowers and fruits per plant.
\end{abstract}

Keywords: Summer Tomato, Gibberellic Acid, Chlorophyll, Soluble protein and Nitrate reductase activity

\section{Introduction}

Tomato (Lycopersicon esculentum) is one of the most popular and nutritious vegetables of Bangladesh (Mondal et al., 2011). Tomato is cultivated all over the country due to its adaptability to a wide range of soil and climate. Normally tomato is grown in winter season due to its requirements for temperate climate. Hence, it is difficult to grow tomato in summer season due to adverse climatic conditions, such as high temperature, high rain fall, hailstorms, etc. Bangladesh Institute of Nuclear Agriculture (BINA) has developed some tomato varieties to cultivate in summer season. But the yield potential of these varieties cannot be achieved due to the above mentioned climatic conditions. In summer season, tomato can however be successfully grown under glasshouse conditions. But it is not possible for the poor farmers to go for large scale production in glasshouses because it is highly expensive and need technical skills. The other option is the use of plant growth regulators to minimize the effect of harsh environments in order to maximize the yield of summer tomato. The application of Gibberellic acid $\left(\mathrm{GA}_{3}\right)$ had significantly increased the number of fruits per plant than the untreated controls (Tomar and Ramgiry, 1997). Adlakha and Verma (1964) reported that the application of GA 3 on flower cluster resulted in an increase in fruit weight. To increase the yield as well as to avoid flower and fruit dropping, application of $\mathrm{GA}_{3}$ at optimum concentration and at right time is important. 
Gibberellic acid has great effects on plant physiological systems including fruit setting, leaf expansion, germination, breaking dormancy, increasing fruit size, improving fruit quality and in many other aspects of plant growth and thereby on crop production. Keeping the above circumstances in view, the study was under taken to evaluate the performance of $\mathrm{GA}_{3}$ on biochemical parameters (chlorophyll, soluble protein and nitrate reductase activity) growth and yield attributes; and to determine the optimum time and concentration of $\mathrm{GA}_{3}$ application in order to maximize the yield of Binatomato-2.

\section{Materials and Methods}

A pot experiment was conducted with tomato var. Binatomato-2 at the experimental site of Crop Botany Department, Bangladesh Agricultural University, Mymensingh during March to July 2012. Five levels of $\mathrm{GA}_{3}$ (Gibberellic Acid) viz. 0, 25, 50, 75 and $100 \mathrm{ppm}$ were applied at (i) seedling stage by root soaking before transplanting (ii) vegetative stage [20 days after transplanting (DAT)] and (iii) flowering stage (40 DAT) by hand sprayer. The experiment was laid out in a randomized complete block design with four replications. Twelve kilograms of sun-dried sandy loam soil and cow dung, urea, TSP and MP @ 583.33, 2.9, 2.54 and 1.81 g/pot corresponding to 10 tons, 400, 350 and 250 $\mathrm{kg} / \mathrm{ha}$ were applied in each pot (BARC, 2005). Before pot filling, full doses of TSP, MP and cow dung were thoroughly mixed with the soil. Half of the urea was applied during transplanting and the remaining half at vegetative stage. Intercultural operations were done as and when necessary. Data on yield and yield contributing characters were recorded at final harvest. Biochemical analyses viz. chlorophyll, soluble protein contents and nitrate reductase activities in leaves were estimated at 50 DAT following the methods of Arnon (1949), Lowry et al., (1951) and Stewart and Orebamjo (1979). Data were analyzed to find out the level of significance using MSTAT-C package programme (Russell, 1986) and significant differences among the treatments were adjudged by Duncan`s New Multiple Range Test (DMRT) at 5\% level of significance (Gomez and Gomez, 1984).

\section{Results and Discussion}

There were significant differences among the treatments in respect of chlorophyll content, soluble protein content and nitrate reductase (NR) activities in tomato leaves at 50 DAT (Table 01). The highest chlorophyll content in leaves was obtained when the roots of seedlings were soaked in $\mathrm{GA}_{3}$ solutions before transplanting, which was identical to the application of $\mathrm{GA}_{3}$ at vegetative stage. The lowest chlorophyll content was found in plants when $\mathrm{GA}_{3}$ was applied at the flowering stage. Chlorophyll content in leaves was influenced significantly due to the application of different concentrations of $\mathrm{GA}_{3}$. The highest chlorophyll content was found from $100 \mathrm{ppm} \mathrm{GA}_{3}$ followed by 75 ppm and the lowest was found from the control, which was identical to those obtained from the application of 25 and $50 \mathrm{ppm}$ of $\mathrm{GA}_{3}$. Chlorophyll content increased with increased concentrations of $\mathrm{GA}_{3}$.

The application of $\mathrm{GA}_{3}$ through root soaking of seedlings and at vegetative stages resulted in the highest but similar soluble protein contents in tomato leaves and the lowest was found when it was applied at the flowering stage. The soluble protein content in leaves was also significantly influenced by the application of variable levels of $\mathrm{GA}_{3}$. The highest content was recorded with $50 \mathrm{ppm}$ and the lowest content was recorded with $100 \mathrm{ppm} \mathrm{GA}$ which indicated that soluble protein content in leaves increased significantly until the application of $50 \mathrm{ppm}$ and thereafter decreased with further increase in $\mathrm{GA}_{3}$ concentrations. Masroor et al., (2006) also reported that $\mathrm{GA}_{3}$ had appreciably increased the protein synthesis in leaves.

The maximum nitrate reductase activity was recorded at vegetative stage. The lowest was observed in flowering stage and this was similar to the activity performed when $\mathrm{GA}_{3}$ was applied through root soaking. Nitrate reductase activity was significantly influenced by the application of different 
concentrations of $\mathrm{GA}_{3}$. The maximum nitrate reductase activity was recorded with $75 \mathrm{ppm} \mathrm{GA}_{3}$ and the minimum was found from the control. Spraying of 50 and $75 \mathrm{ppm} \mathrm{GA}_{3}$ did not show any difference in NR activities at 40 days after planting (Table 01).

Table 01. Effect of GA3 application at different stages of plant growth on bio-chemical parameters of summer tomato var. Binatomato-2 at 40 DAT

\begin{tabular}{|c|c|c|c|}
\hline Treatments & $\begin{array}{l}\text { Chlorophyll content } \\
(\mathrm{mg} / \mathrm{gfw})\end{array}$ & $\begin{array}{l}\text { Soluble protein content } \\
(\mathrm{mg} / \mathrm{gfw})\end{array}$ & $\begin{array}{c}\text { NR activity } \\
\left(\mu \mathrm{moNO}_{2} / \text { gfw/h }\right)\end{array}$ \\
\hline \multicolumn{4}{|l|}{$\mathbf{G A}_{3}$ application } \\
\hline Root soaking & $0.70 \mathrm{a}$ & $2.33 \mathrm{a}$ & $13.20 \mathrm{a}$ \\
\hline Vegetative stage & $0.64 \mathrm{a}$ & $2.32 \mathrm{a}$ & $14.19 \mathrm{a}$ \\
\hline Flowering stage & $0.54 \mathrm{~b}$ & $2.02 \mathrm{~b}$ & $13.07 \mathrm{~b}$ \\
\hline Level of significance & $* *$ & $* *$ & $* *$ \\
\hline$C V \%$ & 7.22 & 8.27 & 4.31 \\
\hline \multicolumn{4}{|c|}{$\mathbf{G A}_{3}$ concentrations $(\mathbf{p p m})$} \\
\hline 0 & $0.58 \mathrm{c}$ & $2.13 \mathrm{c}$ & $11.26 \mathrm{~d}$ \\
\hline 25 & $0.61 \mathrm{bc}$ & $2.42 \mathrm{~b}$ & $13.28 \mathrm{c}$ \\
\hline 50 & $0.62 \mathrm{bc}$ & $2.67 \mathrm{a}$ & $14.15 \mathrm{~b}$ \\
\hline 75 & $0.65 \mathrm{ab}$ & $2.10 \mathrm{c}$ & $14.86 \mathrm{a}$ \\
\hline 100 & $0.67 \mathrm{a}$ & $1.78 \mathrm{~d}$ & $13.90 \mathrm{~b}$ \\
\hline Level of significance & $*$ & $* *$ & $* *$ \\
\hline$C V \%$ & 7.22 & 8.27 & 4.31 \\
\hline
\end{tabular}

The applications of $\mathrm{GA}_{3}$ at different stages of plant growth resulted in significant influence on yield and yield attributes of summer tomato (Table 02). The highest plant height was recorded when $\mathrm{GA}_{3}$ was applied at the vegetative stage and the lowest height was recorded at the flowering stage. $\mathrm{GA}_{3}$ had significant influence on plant height. It increased until the application of $50 \mathrm{ppm}$ and declined remarkably with further increase in $\mathrm{GA}_{3}$ concentrations. The interactions between stage and concentrations of $\mathrm{GA}_{3}$ indicated that the application of $50 \mathrm{ppm}$ of $\mathrm{GA}_{3}$ at the vegetative stage encouraged vigorous plant growth and thereby resulted in the highest plant height.

There was no significant difference among the stages of hormone application in respect of time to first fruit setting. The maximum number of flowers, fruits and fruit weight per plant was produced when $\mathrm{GA}_{3}$ was applied through root soaking followed by the vegetative stage (Table 02). All those parameters showed the lowest results when $\mathrm{GA}_{3}$ was applied at flowering stage. Similar result was also reported by Kaushik et al., 1974. They applied $\mathrm{GA}_{3}$ at vegetative stage and obtained increased fruit weight per plant. Sanyal et al., (1995) observed that foliar application was more effective than root soaking of seedlings. $\mathrm{GA}_{3}$ concentrations had statistically significant effect on plant height, time to first fruit setting, number of flowers, fruits and fruit weight per plant. The highest plant height was found with the application of $50 \mathrm{ppm} \mathrm{GA}$ which was identical to $25 \mathrm{ppm}$ and the lowest was found from the control. The maximum time for first fruit setting was required when $\mathrm{GA}_{3}$ was applied at 100 $\mathrm{ppm}$ and the lowest time was required with lower concentrations of $\mathrm{GA}_{3}$. The maximum number of flowers, fruits and fruit weight per plant was produced with $50 \mathrm{ppm} \mathrm{GA}_{3}$ application and the lowest was recorded with $100 \mathrm{ppm}$. Saleh and Abdul (1980) reported similar result from their experiment. They found that $\mathrm{GA}_{3}$ at $50 \mathrm{ppm}$ decreased the total number of flowers per plant but increased the total yield. Hossain (1974), Adlakha and Verma (1995) found that the application of $50 \mathrm{ppm} \mathrm{GA}_{3}$ had increased the fruit setting, while Saleh and Abdul (1980) observed that $\mathrm{GA}_{3}$ at 25 or $50 \mathrm{ppm}$ had increased the total yield of tomato compared to the control. Sanyal et al., (1995) also found that 50 ppm of $\mathrm{GA}_{3}$ had profound effect on the yield of tomato. 
Table 02. Effect of GA3 application at different stages of plant growth on yield and yield components of summer tomato var. Binatomato-2

\begin{tabular}{|c|c|c|c|c|c|}
\hline Treatments & $\begin{array}{c}\text { Plant height } \\
(\mathrm{cm})\end{array}$ & $\begin{array}{l}\text { Time to first fruit } \\
\text { setting (DAT) }\end{array}$ & $\begin{array}{c}\text { No. of } \\
\text { flowers/plant }\end{array}$ & $\begin{array}{c}\text { No. of } \\
\text { fruits/plant }\end{array}$ & $\begin{array}{l}\text { Fruit wt./ } \\
\text { plant }(\mathrm{g})\end{array}$ \\
\hline \multicolumn{6}{|l|}{$\mathbf{G A}_{3}$ application } \\
\hline Root soaking & $94.20 \mathrm{~b}$ & 40.70 & $22.80 \mathrm{a}$ & $16.25 \mathrm{a}$ & $376.04 a$ \\
\hline Vegetative stage & $104.03 \mathrm{a}$ & 39.90 & $22.25 \mathrm{a}$ & $15.90 \mathrm{a}$ & $372.68 \mathrm{a}$ \\
\hline Flowering stage & $91 . * 98 b$ & 41.45 & $17.85 \mathrm{~b}$ & $13.20 \mathrm{~b}$ & $306.57 \mathrm{~b}$ \\
\hline Level of significance & $* *$ & $n s$ & $* *$ & $* *$ & $* *$ \\
\hline$C V \%$ & 7.75 & 6.50 & 10.37 & 9.05 & 8.73 \\
\hline \multicolumn{6}{|c|}{$\mathbf{G A}_{3}$ concentrations $(\mathbf{p p m})$} \\
\hline 0 & $80.88 \mathrm{~d}$ & $39.50 \mathrm{bc}$ & $18.92 \mathrm{bc}$ & $13.92 \mathrm{c}$ & $321.48 \mathrm{c}$ \\
\hline 25 & $107.21 \mathrm{a}$ & $38.92 c$ & $23.42 \mathrm{a}$ & $16.59 b$ & $382.00 \mathrm{~b}$ \\
\hline 50 & $109.08 \mathrm{a}$ & $39.25 \mathrm{c}$ & $24.58 \mathrm{a}$ & $18.25 \mathrm{a}$ & $427.37 \mathrm{a}$ \\
\hline 75 & $98.67 \mathrm{~d}$ & 41.92ab & $20.25 b$ & $14.58 \mathrm{c}$ & $343.47 \mathrm{c}$ \\
\hline 100 & $87.83 \mathrm{c}$ & $43.83 \mathrm{a}$ & $17.67 \mathrm{c}$ & $12.25 \mathrm{~d}$ & $284.51 \mathrm{~d}$ \\
\hline Level of significance & $* *$ & $* *$ & $* *$ & $* *$ & $* *$ \\
\hline$C V \%$ & 7.75 & 6.50 & 10.37 & 9.05 & 8.73 \\
\hline \multicolumn{6}{|l|}{ Interaction } \\
\hline Root x 0 & $85.25 \mathrm{efg}$ & 40.50bcvd & 19.00def & $14.00 \mathrm{de}$ & $321.80 \mathrm{ef}$ \\
\hline Root x 25 & $105.88 b c$ & 36.50d & $23.00 \mathrm{a}-\mathrm{d}$ & $14.75 \mathrm{~d}$ & 338.75de \\
\hline Root x 50 & $103.50 \mathrm{bc}$ & 39.50bcd & $27.25 \mathrm{a}$ & $20.75 \mathrm{a}$ & $468.60 \mathrm{a}$ \\
\hline Root x 75 & $99.50 \mathrm{~cd}$ & 40.50bcd & $24.00 \mathrm{abc}$ & $16.25 \mathrm{~cd}$ & $397.49 b c$ \\
\hline Root x 100 & $76.87 \mathrm{~g}$ & $46.50 \mathrm{a}$ & 20.75cde & $15.50 \mathrm{~d}$ & $353.57 \mathrm{cde}$ \\
\hline Vegetative $\mathrm{x} 0$ & $81.87 \mathrm{fg}$ & $37.50 \mathrm{~cd}$ & 20.75cde & $15.25 \mathrm{~d}$ & $353.25 \mathrm{cde}$ \\
\hline Vegetative x 25 & $103.25 b c$ & $39.75 \mathrm{bcd}$ & $21.50 \mathrm{~b}-\mathrm{e}$ & $16.00 \mathrm{~cd}$ & $368.15 \mathrm{cde}$ \\
\hline Vegetative x 50 & $127.25 \mathrm{a}$ & $36.50 \mathrm{~d}$ & $24.50 \mathrm{abc}$ & $18.00 \mathrm{bc}$ & $438.42 \mathrm{ab}$ \\
\hline Vegetative $\times 75$ & $107.00 \mathrm{bc}$ & $42.50 \mathrm{abc}$ & $20.75 \mathrm{cde}$ & $15.50 \mathrm{~d}$ & $362.25 \mathrm{cde}$ \\
\hline Vegetative x 100 & $100.75 \mathrm{bcd}$ & $43.25 \mathrm{ab}$ & $23.75 \mathrm{abc}$ & $14.75 \mathrm{~d}$ & $341.32 \mathrm{de}$ \\
\hline Flowering x 0 & $75.50 \mathrm{~g}$ & $40.50 \mathrm{bcd}$ & $17.00 \mathrm{ef}$ & $12.50 \mathrm{e}$ & $289.37 \mathrm{fg}$ \\
\hline Flowering x 25 & $112.50 \mathrm{~b}$ & 40.50bcd & $25.75 \mathrm{ab}$ & 19.00ab & 439.10ab \\
\hline Flowering x 50 & 96.50 cde & $41.75 \mathrm{abc}$ & $22.00 \mathrm{bcd}$ & $16.00 \mathrm{~cd}$ & $375.07 \mathrm{~cd}$ \\
\hline Flowering x 75 & 89.50def & $42.75 \mathrm{ab}$ & $16.00 \mathrm{f}$ & $12.00 \mathrm{e}$ & $270.67 \mathrm{~g}$ \\
\hline Flowering x 100 & $85.87 \mathrm{efg}$ & $41.75 \mathrm{abc}$ & $8.50 \mathrm{~g}$ & $6.50 \mathrm{f}$ & $158.62 \mathrm{~h}$ \\
\hline Level of significance & $\begin{array}{c}* * \\
775\end{array}$ & $*$ & $* *$ & $* *$ & $\begin{array}{c}* * \\
072\end{array}$ \\
\hline$C V \%$ & 7.75 & 6.50 & 10.37 & 9.05 & 8.73 \\
\hline
\end{tabular}

In a column, figures having similar letter(s) do not differ significantly at $5 \%$ level of probability by DMRT. Significant at $5 \%$ level, $* *$ Significant at $1 \%$ level

The interaction between $\mathrm{GA}_{3}$ concentrations and stages of application indicated that the highest number of flowers, fruits and fruit weight per plant were produced when $\mathrm{GA}_{3}$ was applied through root soaking of seedlings at $50 \mathrm{ppm}$ which was identical to the application of $50 \mathrm{ppm}$ at vegetative stage or $25 \mathrm{ppm}$ at flowering stage. A positive and linear relationship was found between the number of flowers per plant and fruit weight per plant $\left(\mathrm{r}=0.96^{* *}\right)$ (Figure 01), number of fruits per plant and fruit weight per plant $(\mathrm{r}=0.99 * *)$ (Figure 02 ) which indicated that the fruit yield of tomato is highly influenced by the production of flowers and the retention of fruits per plant irrespective of the stage and amount of $\mathrm{GA}_{3}$ applied in tomato plants. 


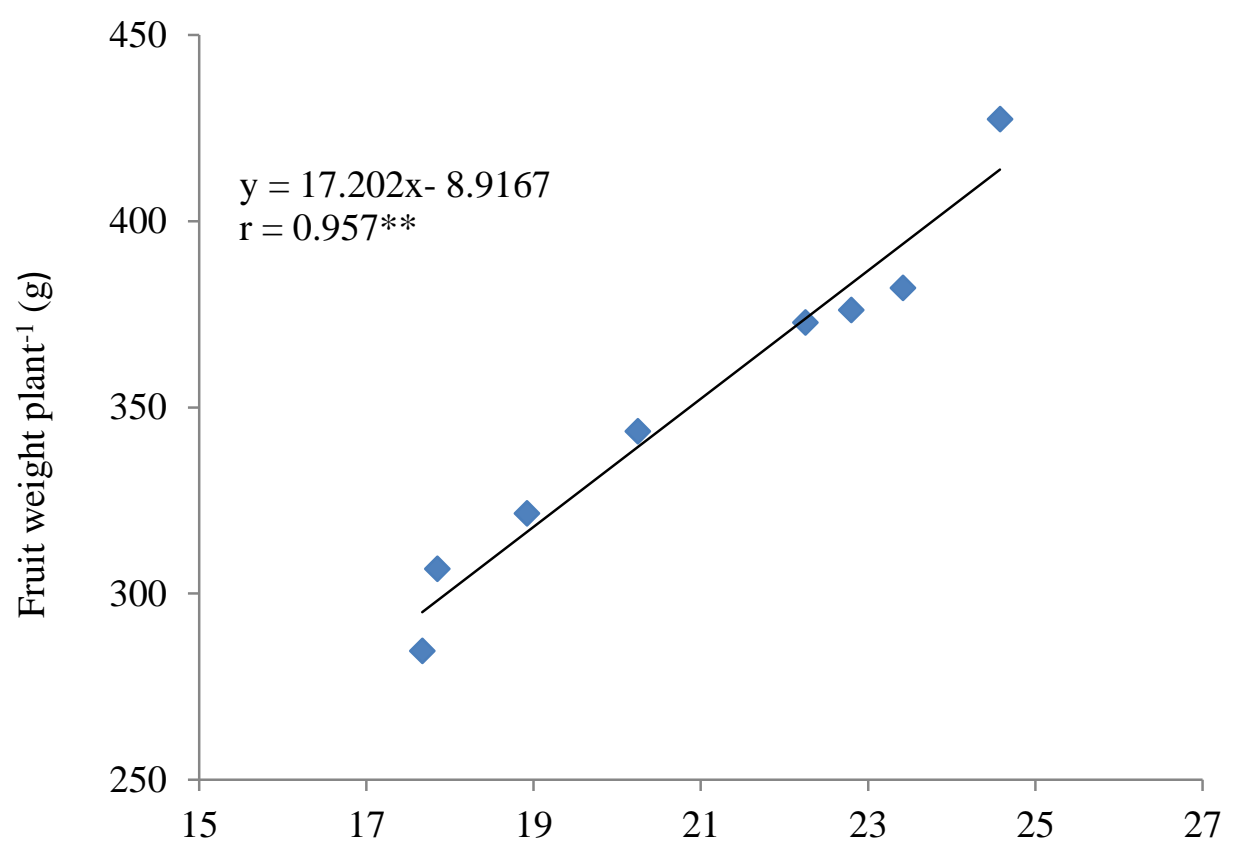

No. of flowers plant ${ }^{-1}$

Figure 01. Relationship between the number of flowers plant ${ }^{-1}$ and fruit weight plant ${ }^{-1}$ of summer tomato var. Binatomato-2

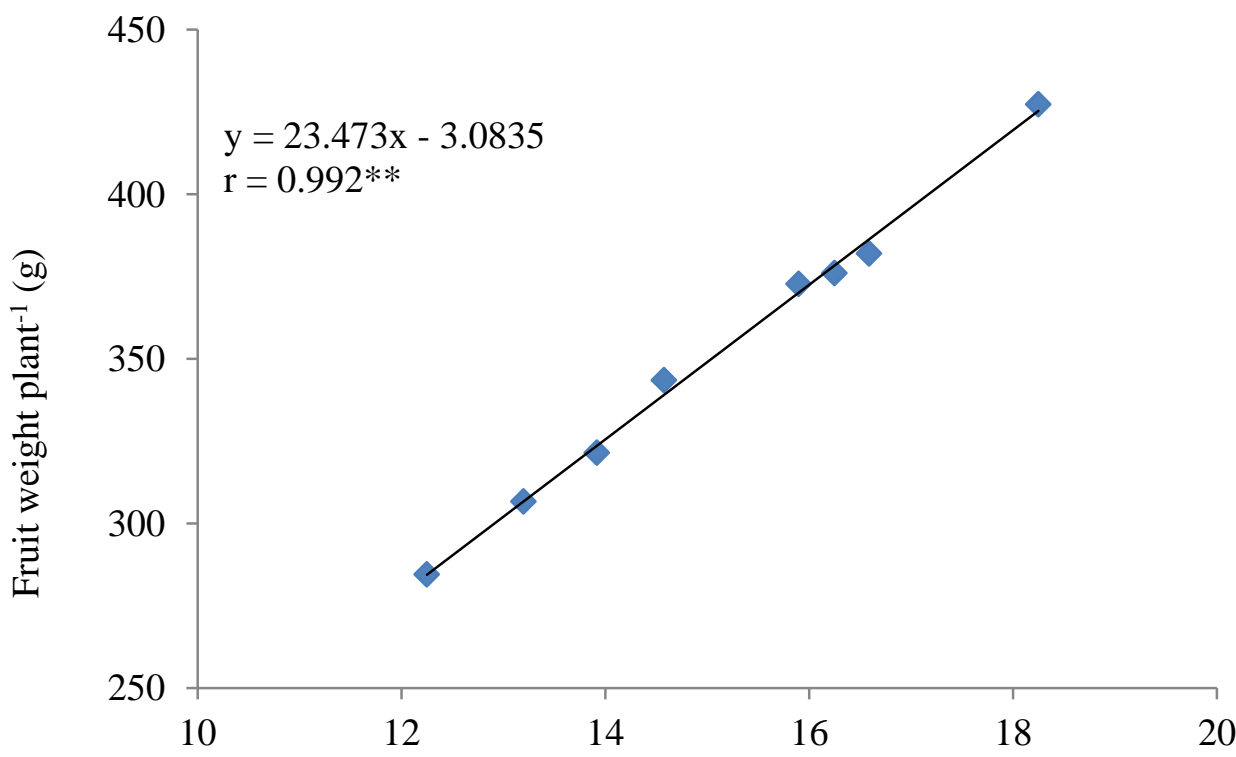

No. of fruits plant ${ }^{-1}$

Figure 02. Relationship between the number of fruits plant ${ }^{-1}$ and fruit weight plant ${ }^{-1}$ of summer $^{-}$ tomato var. Binatomato-2 


\section{Conclusion}

Application of GA3 at the rate of 50-75 ppm by root soaking and at vegetative stage increased biochemical parameters (chlorophyll, soluble protein and nitrate reductase activity) as well as increase the number of flowers, fruits and fruit yield per plant of Binatomato-2. It can be concluded that foliar application of $50 \mathrm{ppm}$ Gibberelic acid on Binatomato-2 variety provide the best result in terms of biochemical attributes and yield.

\section{References}

Adlakha, P. A. \& Verma, S. K. 1995. Effect of gibberellic acid on fruiting and yield of tomatoes. Science and Culture 31, 301-303.

Arnon, D. I. (1949). Copper enzymes in isolated chloroplasts, polyphenol oxidase in Beta vulgaris. Plant Physiology 24, 1-5.

BARC. (2005). Fertilizer Recommendation Guide. Farmgate. Dhaka. p-107.

Gomez, K. A. \& Gomez, A. A. (1984). Statistical Procedures for Agricultural Research. (2 ${ }^{\text {nd }}$ ed.). International Rice Research Institute. John Wiley and Sons, New York, p. 139-240.

Hossain, M. A. E. (1974). Studies on the effect of parachlorophenoxy acetic acid and gibberellic acid on the production of tomato. M. Sc. Ag. Thesis, Dep. of Horticulture, Banglaesh Agricultural University, Mymensingh.

Kaushik, M. P., Sharma, J. K. \& Singh, I. (1974). Effect of alpha naphthalene acetic acid, gibberellic acid, kinetin and morphactin on yield of tomato. Plant Science. 6, 51-53.

Lowry, O. H., Rosebrough, N. J., Farr, A. L. \& Randall, R. J. (1951). Protein measurement with the folin phenol reagent. Journal of Biology and Chemistry 193: 265-275.

Masroor, M., KHAN, A., Gautam, C., Firoz, M., Manzer, H. S., NAEEM, M. M. \& Nasir, K. (2006). Effect of Gibberellic acid spray on performance of tomato. Turkey Journal of Biology 30, 11-16.

Mondal, M. M. A., Imam, M. H. \& Razzaque, A. H. M. (2011). Effect of seasonal seeds on growth and yield of tomato genotypes. International Journal of Experimental Agriculture 2: 12-16.

Russell, D. F. (1986). MSTAT-C Package Programme. Crop and Soil Science Department, Michigan State University, USA.

Saleh, M. M. S. \& Abdul, K. S. (1980). Effect of gibberellic acid and cycocel on growth, flowering and fruiting of tomato (Lycopersicon esculentum Mill.) plants. Mesopotamia Journal of Agriculture 15(1), 137-166.

Sanyal, D., Kar, P. L. \& Longkumar, M. (1995). Effect of growth regulators on the physico-chemical composition of tomato (Lycopersicon esculentum Mill.). Advances in Horticulture and Forestry 4, 67-71.

Stewart, G.R. \& Orebamjo, T.O. (1979). Some unusual characteristics of nitrate reduction in Erythrina senegalensis DC . New Phytology 83, 311-319.

Tomar, I. S. \& Ramgiry, S. R. (1997). Effect of growth regulators on yield and yield attributes in tomato (Lycopersicon esculentum Mill.). Advance Plant Science 10 (2), 29-31.

\section{Citation for this article (APA Style):}

Rahman, M. S., Haque, M. A. \& Mostofa, M. G. (2015). Effect of GA3 on Biochemical Attributes and Yield of Summer Tomato. Journal of Bioscience and Agriculture Research 03(02), 73-78.

Retrieved March 15, 2015 from http://www.journalbinet.com/jbar-volume-03-issue-01.html 